\title{
Maket Kebun Binatang Berbasis Limbah Industri Rumahan sebagai media pembelajaran untuk Anak Usia Dini (AUD)
} Ikhsan Hilmi, D. Nurlatifah, M. Nurhidayati, R. Febrian, Elfan Fanhas F Kh

Universitas Muhammadiyah Tasikmalaya

\begin{abstract}
Abstrak
Kemampuan berfikir abstrak pada Anak Usia Dini (AUD) masih terbatas, dibandingkan dengan kemampuan berfikir konkrit, sehingga kegiatan bermain sambil belajar bagi Anak Usia Dini (AUD) akan efektif apabila anak dibawa pada keadaan dan kondisi yang sebenarnya.

Mengenalkan dunia binatang (fauna) yang efektif untuk Anak Usia Dini (AUD) haruslah dibawa pada keadaan dan kondisi kebun binatang yang sebenarnya, tetapi bagi anak yang tinggal jauh dan atau di daerahnya tidak terdapat kebun binatang tentu hal ini menjadi kendala khususnya berkenaan dengan pendanaan, oleh karenanya kemampuan pendidik membuat maket sebagai media pembelajaran sangatlah penting karena hal tersebut dapat terjangkau dan dapat menggunakan bahan-bahan dari limbah industri rumahan yang ada di lingkungan sekitar.

Langkah-langkah membuat maket binatang berbasis limbah industri rumahan, adalah sebagai berikut : mengumpulkan bahan-bahan, membuat pola, membuat bentuk, merangkai, mewarnai, serta memberi aksesoris dan binatang mainan. Maket kebun binatang yang sudah jadi dapat dijadikan media pembelajaran yang menyenangkan bagi Anak Usia Dini (AUD) untuk mengenal bentuk, warna, bilangan, sipat dan karakter, dan hal lainnya.
\end{abstract}

Kata Kunci : Maket, Limbah industri, dan media pembelajaran

\section{A Zoo Mockup based on Household waste Industry as a Learning Media for Early Childhood (AUD)}

\begin{abstract}
Abstract thinking ability in Early Childhood (AUD) is still limited than concrete thinking ability, so that learning activities for Early Childhood (AUD) will be effective if the child is brought to the real condition.

Introducing an animal life for Early Childhood (AUD) effectively is should be brought to the real condition of the zoo, but for children living far away and / or in their areas there is no zoo, this is an obstacle especially deals with funding issues. Therefore the teacher's ability to make a mockup as a learning media is very important because it can be affordable and can use existing materials from home industry wastes in the environment.

The steps to create a zoo mockup based on home industry waste are as follows: collecting materials, making patterns, making shapes, stringing, coloring, giving accessories and animals toys. A ready zoo mockup can be used as a fun learning media for Early Childhood (AUD) to recognize shapes, colors, numbers, characters, and other things.
\end{abstract}

Keyword : Maket (Mockup), home industry waste, Learning Media 


\section{Pendahuluan}

Fase Anak Usia Dini (AUD) adalah fase yang sangat strategis untuk mengenalkan segala macam yang ada di alam semesta ini, manusia pada tahapan Anak Usia dini merupakan masa keemasan (golden ages) untuk meletakkan fondasi pendidikan yang baik (Elfan Fanhas F K, 2016 : 2) karena dapat mudah menerima informasi dan pengetahuan, tetapi jangan sampai salah kaprah dengan mencekoki anak, memaksa anak untuk belajar dan melarang bermain, sehingga menjadi beban AUD yang berakibat pada keadaan trauma.

Karakteristik dan sifat-sifat anak usia dini menurut M. Solehudin dan Ihat Hatimah dalam (Syamsu yusuf LN dan Nani M Sugandhi, 2011 : 48-50) yaitu : unik, egosentris, aktif dan energik, rasa ingin tahu yang kuat dan antusias pada banyak hal, eksploratif dan berjiwa petualang, spontan, senang dan kaya dengan fantasi, masih mudah frustasi, masih kurang pertimbangan dalam melakukan sesuatu, daya perhatian yang pendek, bergairah untuk belajar dan banyak belajar dari pengalaman, serta semakin menunjukkan minat terhadap teman.

Christianna (2013:7) berpendapat bahwa pendidikan anak usia dini merupakan pendidikan yang paling mendasar menempati posisi yang sangat strategis dalam pengembangan sumber daya manusia, dengan demikian pendidikan anak usia dini menjadi akar penanaman karakter kepada generasi penerus bangsa agar menjadi generasi yang beradab dan menjunjung akhlakul karimah. Proses kegiatan belajar mengajar untuk anak usia dini difokuskan pada stimulasi perkembangan anak, baik perkembangan kognitif, psikomotor, adaptif dan afektif. Maka dari itu kegiatan pembelajaran untuk AUD haruslah bervariasi dan sesuai dengan tugas perkembangannya berdasarkan psikologi perkembangan AUD dan juga menggunakan banyak media pendidikan. Menurut christianna (2013:7) hendaknya dilakukan dengan tujuan memberikan konsep-konsep dasar yang memiliki kebermaknaan bagi anak melalui pengalaman nyata yang memungkinkan anak untuk menunjukkan aktivitas dan rasa ingin tahu (curiosity) secara optimal. Penggunaan media pembelajaran yang inovatif dan kreatif dalam proses belajar mengajar menjadi sangat penting bagi tercapainya tujuan pembelajaran, selain itu pemakaian media pembelajaran dalam proses belajar mengajar dapat membangkitkan moyivasi dan rangsangan kegiatan belajar dan bahkan membawa pengaruh psikologis terhadap anak (Arsyad, 2008 : 15). 
Media pembelajaran memiliki fungsi, untuk : (1) Pemusat perhatian anak; (2) Menggugah emosi anak; (3) Membantu anak memahami materi pembelajaran; (4) Membantu anak mengorganisaikan informasi: (5) Membangkitkan motivasi belajar siswa; (6) Membuat pembelajaran menjadi lebih kongkret; (7) Mengatasi keterbatasn ruang; (8) Mengaktifkan pembelajaran; (9) Mengurangi kemungkinan pembelajaran yang berpusat pada guru, dan; (10) Mengaktifkan respon siswa. (Sadiman, 2010 : 17).

Teori perkembangan kognitif Piaget sebagaimana dikemukanan oleh Santrock (2010 : 25) sebagai berikut : Tahap sensorimotorik, yang berlangsung dari lahir sampai sekitar 2 tahun, pada tahap ini anak membangun pemahaman tentang dunia dengan mengkoordinasikan pengalaman sensorik (seperti penglihatan dan pendengaran) dengan fisik. Tahap praoperasional, yang berlangsung dari sekitar 2 sampai 7 tahun. Pada tahap ini, anak mulai melampaui hanya menghubungkan informasi sensorik dengan tindakan fisik dan mewakili dunia dengan kata-kata dan gambar, namun menurut Piaget anak-anak prasekolah masih kekurangan kemampuan untuk melakukan apa yang ia sebut dengan operasional, yaitu tindakan mental terinternalisasi yang memungkinkan anak-anak untuk melakukan aktifitas mental yang sebelumnya hanya bisa dilakukan secara fisik. Dari tahapan perkembangan kognitif tersebut maka media yang tepat dalam proses pembelajaran anak yaitu menggunakan maket atau miniatur, terlebih anak diajarkan untuk dapat mendaur ulang limbah sehingga memiliki kesadaran untuk berperan aktif menjaga dan melestarikan lingkungannya.

Pembuatan maket kebun binatang berbasis limbah insudtri rumahan untuk media pembelajaran anak usia dini diharapkan menjadi inspirasi dan atau referensi bagi para guru, maupun orang tua untuk berkreasi dan berinovasi dalam mendidik anaknya menggunakan media pembelajaran yang tepat, murah dan ramah lingkungan.

\section{Pembahasan}

\section{Maket sebagai Media Pembelajaran}

Media pembelajaran yang efektif menjadi hal yang menentukan dalam proses pendidikan untuk mencapai tujuan pendidikan, menurut Mc Luahan (Mudlofir et.al, 2016 : 122) media adalah saluran karena pada hakikatnya media telah memperluas atau memperpanjang kemampuan manusia untuk merasakan, 
mendengar dan melihat dalam batas-batas jarak, ruang dan waktu tertentu dengan bantuan itu batas-batas menjadi tidak ada, terlebih untuk Anak Usia Dini (AUD) yang kemampuan berfikirnya masih bersifat konkrit sangat memerlukan media pembelajaran untuk mengkonkritkan sebuah konsep sehingga mudah dipahami.

Maket adalah salah satu media pembelajaran yang ekonomis, mudah, memiliki daya tarik serta memiliki nilai edukatif yang cukup tinggi dilihat dari keefektifan media ini anak bisa mempresentasikan kehidupan nyata di sekelilingnya. Menurut Sunaryo (2009 : 85) Maket adalah bentuk tiruan tentang sesuatu dalam ukuran kecil. Media pembelajaran maket yang efektif dan mempunyai nilai, baik nilai seni, sosial, budaya, moral yang sesuai dengan perkembangan psikologi Anak Usia Dini (AUD).. Petrakos, H \& Howe, N (1996 : 74) menyatakan bahwa miniatur dapat dibangun untuk mempresentasikan kehidupan nyata atau lingkungan sekitar anak. Media pembelajaran maket disajikan dengan semenarik mungkin sehingga anak akan termotivasi untuk belajar, anak akan lebih faham apabila dihadirkan miniatur materi yang sedang diajarkan sehingga guru mudah dalam mengajar.

\section{Limbah Industri Rumahan sebagai Bahan Maket}

Limbah industri rumahan sering kali menjadi pemicu konflik sosial di masyarakat karena ketidak tahuan pelaku usaha industri rumahan bagaimana menangani limbah sehingga tidak berdampak pada lingkungan sekitar. Limbah adalah bahan sisa yang tidak terpakai yang dihasilkan oleh sebuah industri rumahan yang ada dilingkungan sekitar. Menurut Dahruji, Pipit Festi, dan Totok Hendarto (2016 : 33-34) Jenis-jenis limbah Jika didasarkan asalnya, limbah dikelompokkan menjadi 2 yaitu :

a. Limbah Organik

Limbah ini terdiri atas bahan-bahan yang bersifat organik seperti dari kegiatan rumah tangga, kegiatan industri. Limbah bisa dengan mudah diuraikan melalui proses yang alami, misalnya dari pestisida, begitu pula dengan pemupukan yang berlebihan. Limbah ini mempunyai sifat kimia yang stabil sehingga zat tersebut akan mengendap kedalam tanah, dasar sungai, danau, serta laut dan selanjutnya akan mempengaruhi organisme yang hidup didalamnya. Sedangkan limbah rumah tangga berupa seperti kertas, plastik dan 
air cucian. Limbah tersebut mempunyai racun yang tinggi misalnya : sisa obat, baterai bekas, dan air aki. Limbah tersebut tergolong (B3) yaitu bahan berbahaya dan beracun, sedangkan limbah air cucian, limbah kamar mandi, dapat mengandung bibit-bibit penyakit atau pencemaran biologis seperti bakteri, jamur, virus dan sebagainya.

b. Limbah Anorganik

Limbah ini terdiri atas limbah industri atau limbah pertambangan. Limbah anorganik berasal dari sumber daya alam yang tidak dapat di uraikan, tidak dapat diperbaharui. Limbah industri dapat berbentuk Garam anorganik seperti magnesium sulfat, magnesium klorida yang berasal dari kegiatan pertambangan dan industri, Asam anorganik seperti asam sulfat yang berasal dari industri pengolahan biji logam dan bahan bakar fosil, Adapula limbah anorganik yang berasal dari kegiatan rumah tangga seperti botol plastik, botol kaca, tas plastik, kaleng dan aluminium.

Industri rumahan yang ada di kota Tasikmalaya adalah industri kerajinan mendong, anyaman, sandal, kelom geulis, payung geulis, batik tasik, bordiran, dan meubelair.

Industri rumahan kerajinan mendong yang ada di daerah kecamatan Purbaratu mengolah tanaman mendong menjadi produk-produk bernilai jual, seperti : tikar, sandal, tempat tissu, tempat koran, dan lainnya. Industri rumahan kerajinan anyaman yang berada di daerah kecamatan Rajapolah yang mengolah tanaman mendong, eceng gondok, lidi, daun panama, kulit kayu, dan bambu yang diubah menjadi aneka macam kerajinan kebutuhan rumah tangga maupun aksesoris. Industri rumahan sandal, kelom geulis, dan meubelair yang ada di daerah kecamatan Tamansari mengolah spon, karet, kayu, dan kulit imitasi menjadi sandal maupun kelom geulis, serta menghasilkan bahan setengah jadi dalam bentuk lemari, meja, maupun kursi. Industri rumahan batik tasik yang ada di daerah Kecamatan Cipedes menghasilkan produk batik tulis maupun cetak. Sedangkan industri rumahan yang ada di daerah kecamatan Kawalu adalah pengrajin bordilan.

Industri rumahan tersebut diatas banyak menghasilkan limbah berupa potongan-potongan atau sisa-sisa bahan yang tidak dapat digunakan, dan hal ini 
sering menjadi masalah dalam pemusnahannya. Pemanfaatan limbah tersebut menjadi bahan pembuatan media pembelajaran merupakan usaha baik untuk mendaur ulang dan meminimalisir dampak buruk pada lingkungan

\section{Tahapan Pembuatan Maket Kebun Binatang}

Tahapan pembuatan maket kebun binatang berbasis limbah industri rumahan, sebagai berikut :

a. Mengumpulkan bahan berupa limbah industri rumahan dan peralatan yang dibutuhkan

Bahan yang harus disediakan adalah :

1) Serbuk kayu sisa hasil penggergajian

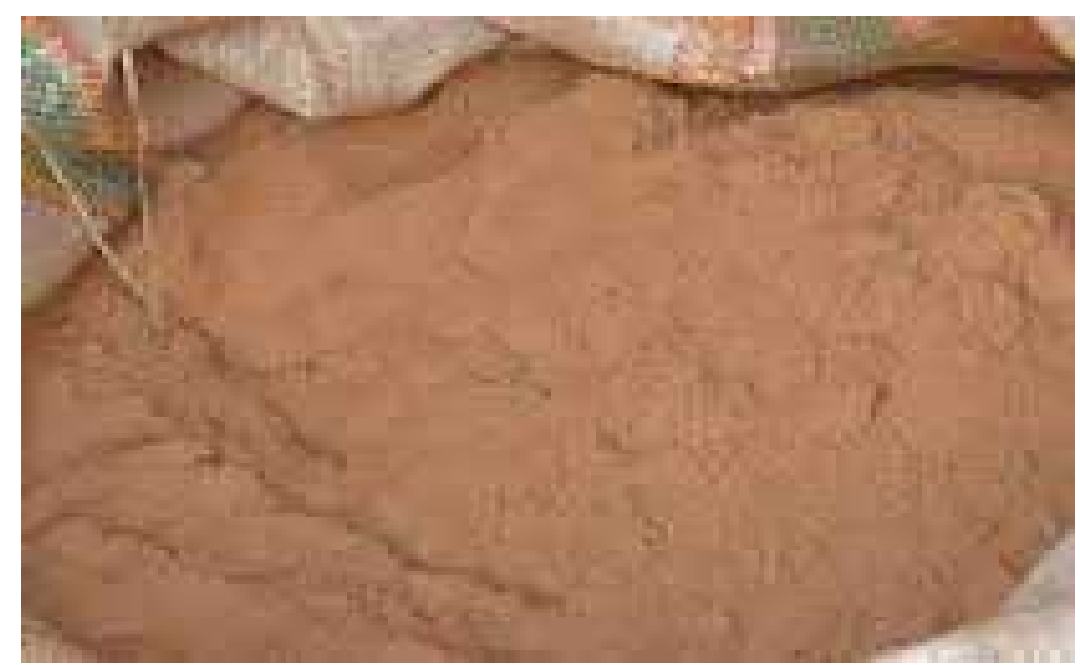

Gambar 1:

Serbuk kayu 
2) Triplek atau papan

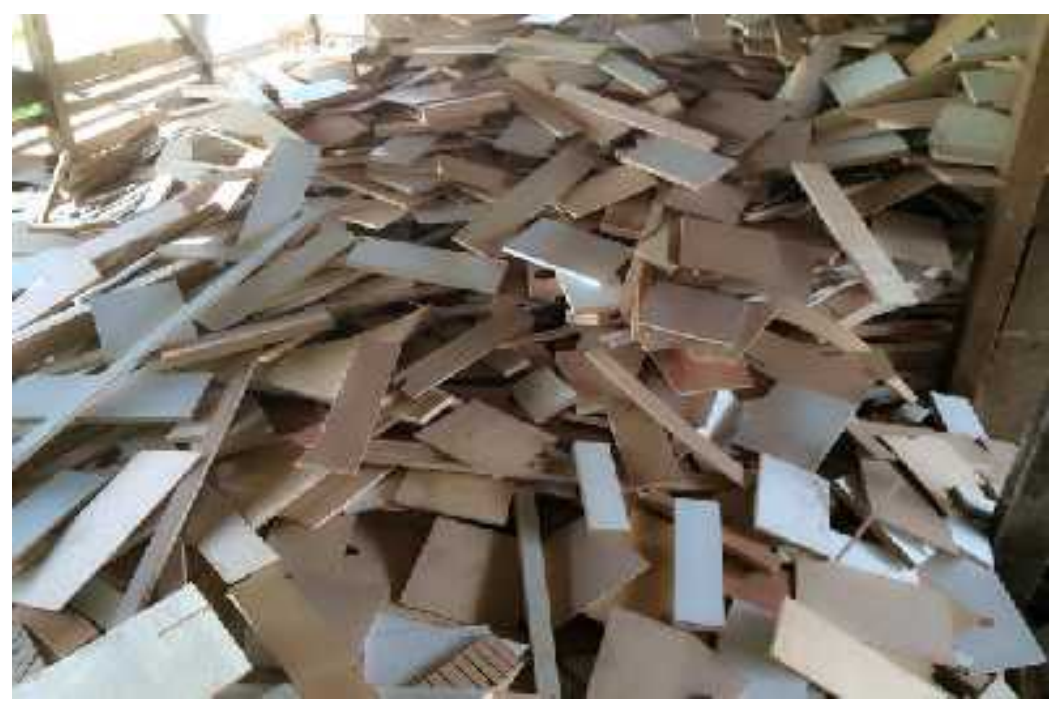

Gambar 2 :

Potongan triplek

3) Spon

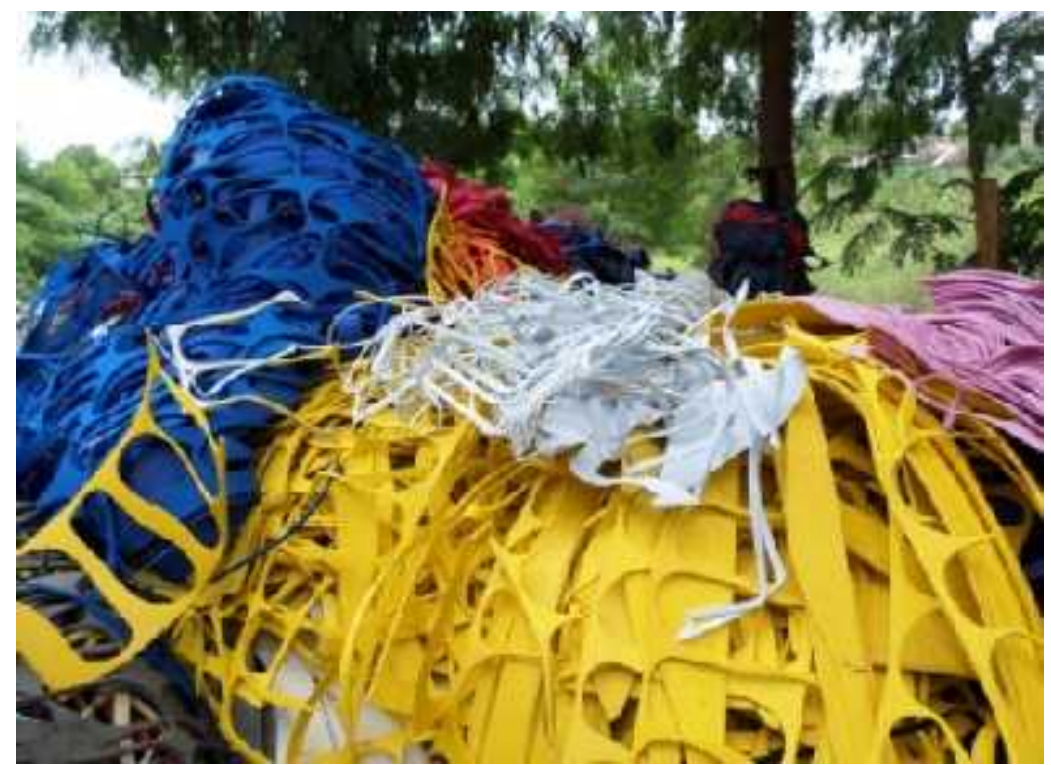

Gambar 3 :

Potongan spon sisa 
4) Stik ice cream

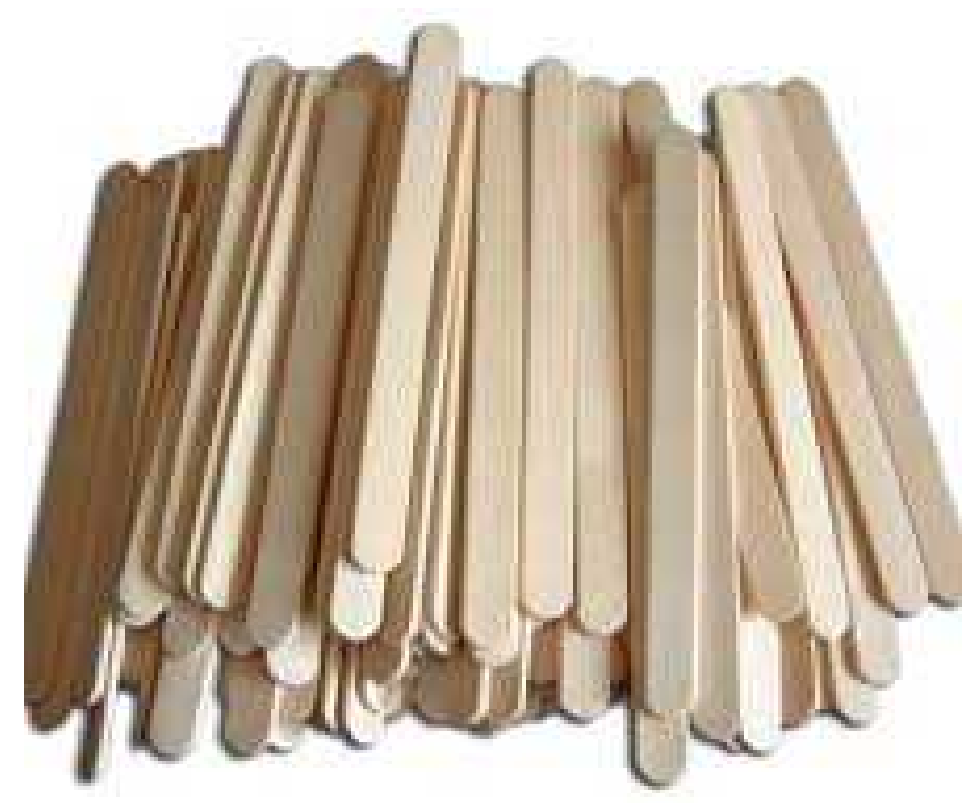

Gambar 4 :

Stik ice cream

5) Kain Percak batik tasik

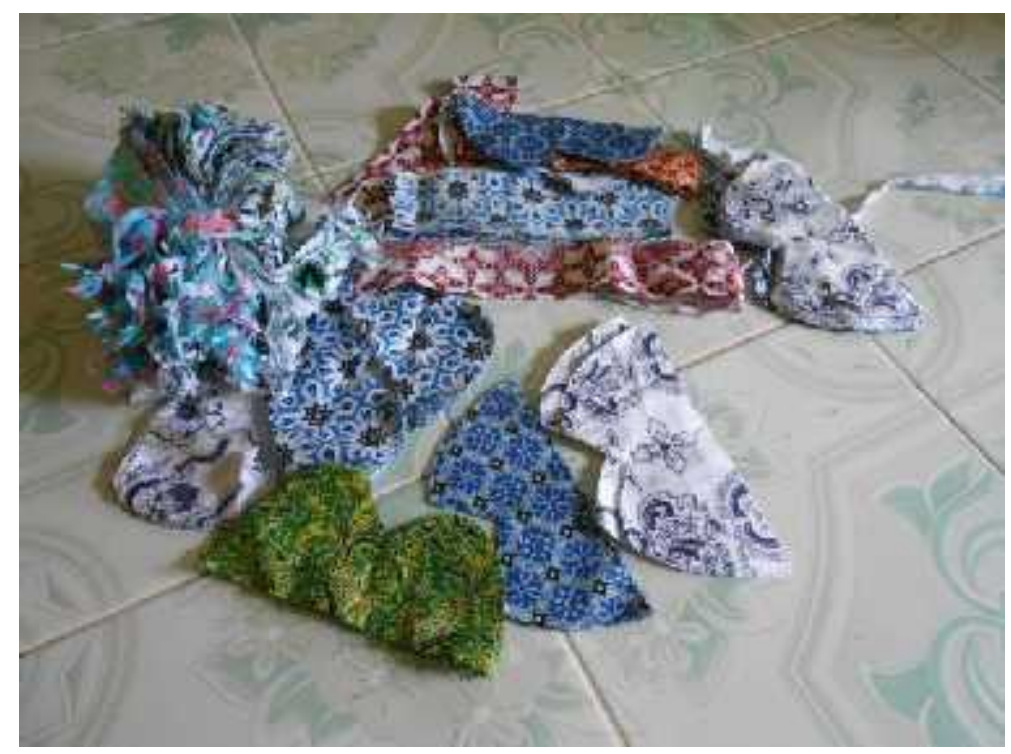

Gambar 5 :

Kain Percak batik

Sedangkan peralatan yang harus disediakan, adalah :

(1). Gergaji

(2). Gunting 
(3). Pisau/ cutter

(4). Penggaris dan pensil

(5). Lem Kayu

(6). Pewarna makanan dan cat secukupnya

(7). 1 set binatang dari plastik

b. Mensterilkan bahan sehingga aman untuk anak

Setelah bahan-bahan untuk pembuatan maket kebun binatang terkumpul, maka bahan tersebut disortir dan dikelompokkan sesuai dengan jenis bahan, kemudian disterilkan dengan cara melakukan pencucian dan penjemuran, selain itu pilihlah cat yang ramah dan aman terhadap anak

c. Membuat pola kebun binatang

Pembuatan pola kebun binatang diawali dengan melakukan identifikasi binatang yang akan dikenalkan pada anak, sehingga dapat diketahui tempat tinggal (ekosistem) binatang tersebut. Selanjutnya membuat rancangan kandang yang tepat sesuai dengan binatang yang akan mengisinya disesuaikan juga dengan kebiasan hidup binatang, misalkan orang utan yang biasa hidup di pohon maka pada kandangnya diberi miniatur pohon, atau gajah yang biasa berendam di kolam maka pada kandangnya dibuatkan miniatur kolam.

Pola sebelum digambar pada triplek, dibuatkan pola pada kertas minyak atau koran bekas. selain pola digambar pada triplek yang menjadi dasar pembuatan maket kebun binatang, juga dibuatkan pola untuk aksesorisnya baik pola gunungan, pohon, batuan, dan lainnya.

d. Memotong dan membentuk bahan sesuai dengan pola

Memotong dan atau menyambung triplek sebagai dasar pembuatan maket kebun binatang, ukuran triplek sebagai dasar pembuatan kebun binatang disesuaikan dengan jumlah kandang yang akan dibuat, tetapi harus diperhatikan juga aspek ruangan tempat bermain sambil belajar, jangan sampai maket menggunakan ruangan yang besar sehingga ruangan tersebut menjadi sempit. Kemudian memotong dan membentuk spon dan kain percak sesuai dengan pola untuk pembuatan dasar kandang dan aksesoris kebun binatang. 
e. Merangkai bahan pada triplek yang telah diberi pola gambar

Pada tahap ini triplek yang sudah diberi pola dan dilapisi dengan potongan spon sebagai dasar, kemudian diberi lem kayu secukupnya, kemudian ditaburi dengan serbuk kayu yang telah diberi pewarna makanan dengan beraneka warna disesuaikan dengan warna tempat tinggal binatang tersebut. Dasar kebun binatang selain berbentuk datar, dibentuk juga dalam bentuk kolam, gunungan, dan bebatuan.

f. Merwarnai dan memberi aksesoris

Proses pewarnaan maket kebun binatang dilakukan setelah seluruh rangkaian ditempatkan pada pola yang ada, serta telah kering karena proses pengeringan secara alami. Warna disesuaikan dengan warna aslinya dan menarik perhatian anak.

Langkah selanjutnya adalah penempatan binatang plastik pada kandang yang telah dibuat.

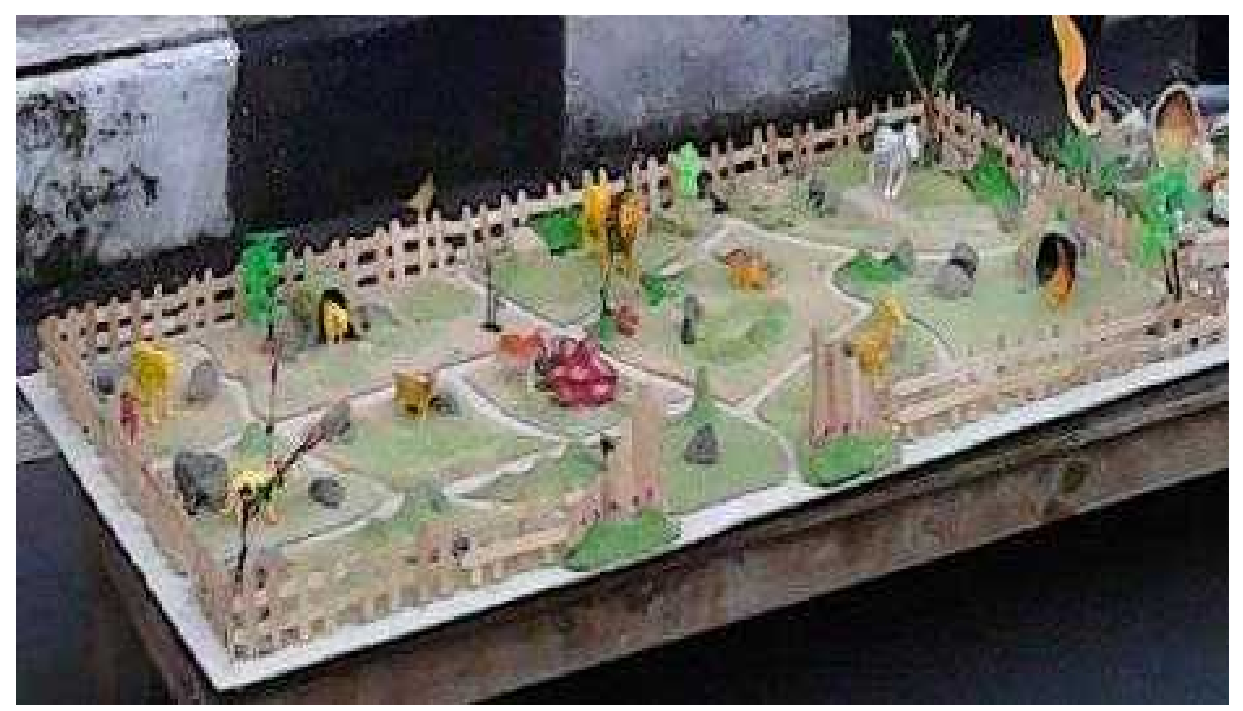

Gambar 6 :

Maket yang telah diberi warna dan aksesoris

\section{Peraturan penggunaan media maket}

Penggunaan media maket harus dengan bimbingan dan arahan tutor serta dilakukan secara berkelompok, sehingga maksud dan tujuan dari bermain sambil belajar tercapai. Adapun langkah-langkah yang harus dilakukan adalah : 
a. Tutor menentukan tujuan bermain sambil belajar yang ingin dicapai secara tematik

b. Tutor menyampaikan aturan main kepada anak

c. Anak bermain secara bergilir dengan arahan tutor

d. Tutor mengevalusi dengan cara meminta anak menceritakan dan atau mempraktekkan kembali apa yang telah dilakukannya.

e. Selesai bermain tutor mengarahkan anak untuk merapikan media seperti semula.

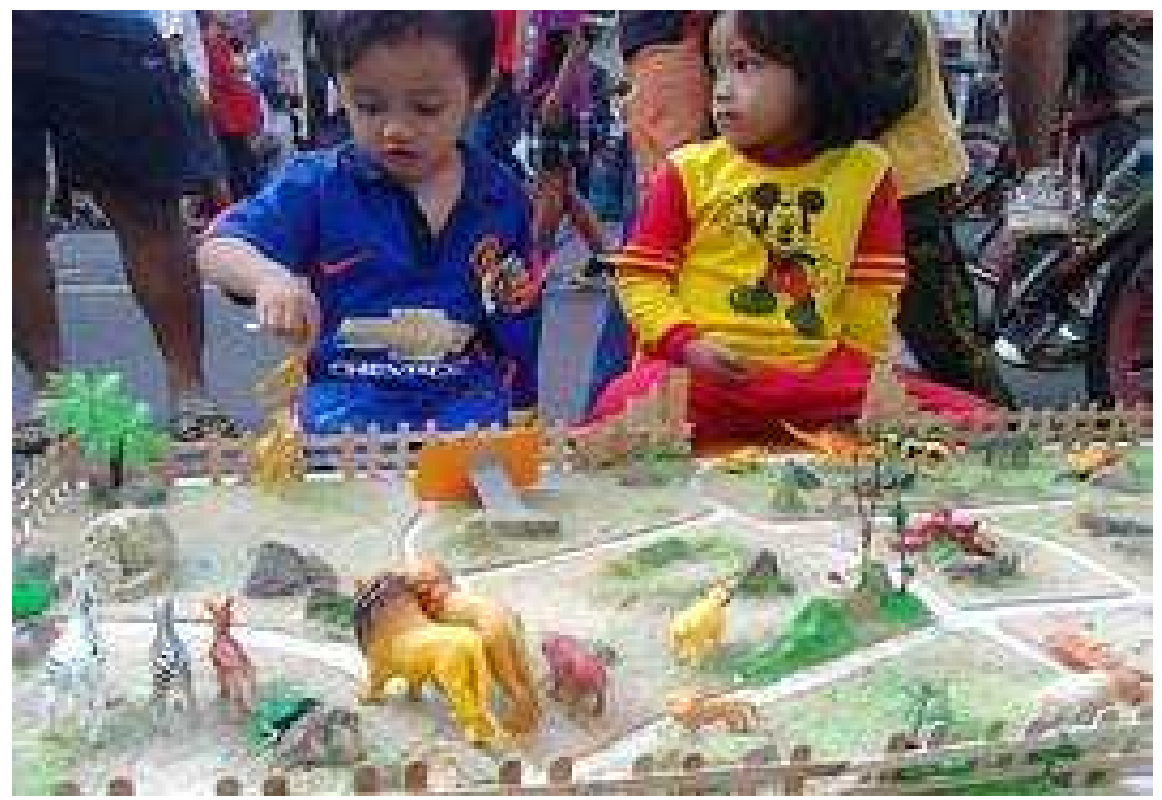

Gambar 7 :

Gambaran anak bermain maket

\section{Simpulan}

Langkah-langkah pembuatan maket kebun binatang berbasis limbah industri rumahan sebagai media pembelajaran anak usia dini, adalah sebagai berikut : mengumpulkan bahan berupa limbah industri rumahan dan peralatan yang dibutuhkan, mensterilkan bahan sehingga aman untuk anak, Membuat pola kebun binatang, Memotong dan membentuk bahan sesuai dengan pola, Merangkai bahan pada triplek yang telah diberi pola gambar, Merwarnai dan memberi aksesoris binatang dari plastik 


\section{Daftar Pustaka}

Arsyad A. 2008. Media Pembelajaran. Jakarta : Raja Grafindo Persada.

Christianna, Aniendya. 2013. Pelatihan Perancangan Alat Permainan Edukatif (Ape) Berbasis Bahan Bekas Untuk Pendidikan Anak Usia Dini (Paud) SeSiwalankerto Surabaya. Journal of Service Learning. Vol. 1, No. 1, December 2013.

Dahruji, Pipit Festi, Totok Hendarto. Studi Pengolahan Limbah Usaha Mandiri Rumah Tanggadan Dampak bagi Kesehatan di Wilayah Kenjeran. Jurnal pengabdian masyarakat Axiologiya. Vol. 1, No. 1 tahun 2016

Fanhas, Elfan. Metode becakap-cakap bagi Anak Usia Dini : Beradasarkan analisis deskriptif terhadap Al-Qur'an Surat Al-Baqarah : 30-33. Jurnal Naturalistic. Vol 1, No. 1 Oktober 2016.

Petrakos dan Howe. 1996. The Influence of the Physical Designof the Dramatic Play Center on Children's Play.Early Childhood Research Quarterly, 11, 63-77. 1996.

Rusydiyah dan Mudlofir. 2016. Desain Pembelajaran Inovatif dari Teori ke Praktek. Jakarta : PT Raja Grafindo Persada.

Sadiman, Arief S. 2010. Media Pendidikan : Pengertian, Pengembangan, dan Pemanfaatannya. Jakarta : Rajawali Pers

Santrock, John, W. 2010. Life Span Development (Thirteenth Edition). Published by McGraw-Hill, an imprint of The McGraw-Hill Companies University of Texas at Dallas.

Sunaryo. Pengaruh Penggunaan Media Maket terhadap Prestasi BelajarSiswa Tunagrahita Ringanpada Mata Pelajaran IPA. Jurnal Pengaruh penggunaan media maket Volume 8 : Nomor 2 Tahun 2009.

Yusuf LN, Syamsu, dan Sugandhi, Nani M, 2011. Perkembangan pesereta didik. Jakarta : PT Raja Grafindo Persada 